\title{
Pemberdayaan Kelompok Tani dan Pengembangan Kampung Sayur Bausasran di Masa Pandemi Covid 19
}

\author{
Dwi Aditiyarini $^{\# 1}$, Catarina Aprilia Ariestanti ${ }^{\# 2}$, Aniek Prasetyaningsih ${ }^{\# 3}$, Timothy Charles Wherrett ${ }^{\# 4}$, Hardo \\ Firmana Given Grace Manik ${ }^{* 5}$, Katon Wijana ${ }^{3}$

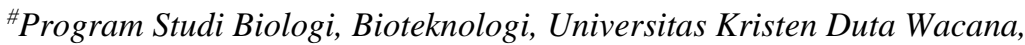 \\ Jl. dr. Wahidin Sudirohusodo no. 5-25 Yogyakarta \\ 11wi.aditiyarini@staff.ukdw.ac.id \\ ${ }^{2}$ catarina.ariestanti@staff.ukdw.ac.id \\ 3 aniek@staff.ukdw.ac.id \\ ${ }^{4}$ tim@staff.ukdw.ac.id \\ *Program Studi Manajemen, Fakultas Bisnis, Universitas Kristen Duta Wacana \\ Jl. dr. Wahidin Sudirohusodo no. 5-25 Yogyakarta \\ 5hardofggmanik@staff.ukdw.ac.id \\ -Program Studi Sistem Informasi, Fakultas Teknologi Informasi, Universitas Kristen Duta Wacana \\ Jl. dr. Wahidin Sudirohusodo no. 5-25 Yogyakarta \\ 6katony@staff.ukdw.ac.id
}

\begin{abstract}
Abstrak-Kampung Sayur Bausaran merupakan salah satu daerah percontohan dalam pertanian perkotaan di Kota Yogyakarta. Akan tetapi, kondisi pandemi Covid 19 menyebabkan penurunan produktivitas dan keterlibatan masyarakat dalam pertanian perkotaan ini. Melihat kondisi tersebut, civitas akademika UKDW tergerak untuk terlibat dalam keberlangsungan pertanian perkotaan di Bausasran. Program pengabdian ini bertujuan untuk memberdayakan 6 kelompok tani dan 1 lahan Gerakan Pekarangan Pangan di Kampung Bausasran melalui pembinaan sumber daya manusia, usaha, lembaga dan lingkungan. Pendekatan yang digunakan dalam program pengabdian ini meliputi pelatihan, penerapan dan simulasi pengetahuan dan teknologi. Kegiatan diawali dengan survey dan pemetaan kebutuhan masingmasing kelompok tani melalui wawancara secara langsung dengan pengurus kelompok tani. Berdasarkan hasil survey dan wawancara, terdapat perbedaan kebutuhan masingmasing kelompok tani berdasarkan kondisi, lokasi dan luas lahan pertanian. Meskipun demikian, program utama yang dibutuhkan masih terkait dengan pertanian. Metode bercocok tanam hidroponik secara sederhana menjadi salah satu solusi bagi pertanian perkotaan. Program pendukung meliputi usaha memperindah Kampung Sayur dan perbaikan manajemen serta administrasi. Program tersebut ditujukan untuk mengembangkan Kampung Sayur ke arah kawasan ekowisata berbasis edukasi pertanian. Pelaksanaan program
\end{abstract}

ini disambut baik oleh perangkat desa dan pengurus kelompok tani. Lorong sayur yang hijau, diversifikasi produk olahan dan ketersediaan website dan media sosial untuk promosi merupakan bentuk pengembangan kelompok tani. Evaluasi dan perbaikan yang perlu dilakukan adalah pemetaan potensi kelompok tani yang lebih dalam dan rinci sehingga keunggulan dan potensi lokal yang ada dapat dikembangkan. Selain itu, diperlukan program pembinaan sumber daya manusia untuk meningkatkan motivasi masyarakat dalam memajukan pertanian perkotaan.

Kata kunci-ekowisata, kelompok tani, kampung sayur, pandemi, SDM

Abstract - Kampung Sayur Bausasran is a pilot area for urban agriculture in Yogyakarta. However, the Covid 19 pandemic has caused a decline in productivity and community involvement in urban agriculture at Bausasran. In response to this situation, UKDW as an educational institution was moved to be involved in the sustainability of urban agriculture in Bausasran. The purpose of this service program is to empower six farming groups through the development of human resources, business, administrative procedures, and the local environment. The approaches used in this program were training members of the farming groups, application and simulation of science and technology solutions. Initially, the 
needs of the farming groups were surveyed and mapped through direct interviews with the head of each farming group. These initial results indicated that the main need was still directly related to farming, with supporting programs including administration, management, and promotion. The simple hydroponic farming method is one solution for urban farming in this area. These programs aimed to develop Kampung Bausasran to become an ecotourism area based on agricultural education. The implementation of these programs was welcomed by local government and the farming groups. Several improvements were observed, such as the green vegetable alleys, diversification of vegetables grown and the creation of a website and social media account for promotion. Evaluation and mapping of the specific potential of each farming group is needed for further improvement and development of the area. In addition, a program of human resource development is needed to develop urban agriculture at Bausasran.

Keywords-ecotourism, farmer group, human resources, Kampung Sayur, pandemic

\section{Pendahuluan}

Kampung Bausaran merupakan salah satu kampung yang terletak di tengah perkotaan Yogyakarta, tepatnya di Kecamatan Danurejan Yogyakarta dengan luas $0,47 \mathrm{~km}^{2}$. Sejak tahun 2009, Kampung Bausasran telah merintis kegiatan pertanian perkotaan dengan memanfaatkan lahan sempit yang tersedia, seluas $400 \mathrm{~m}^{2}$. Hingga saat ini, terdapat enam kelompok tani yang tersebar di 4 RW dan 20 RT, yaitu Kelompok Tani Dewasa (KTD) Gemah Ripah, Kelompok Tani (Poktan) Bonjowi, Poktan Bustan Adi, Poktan Manunggal Lestari, Poktan Amanah dan Poktan Sumur Bening. Poktan-poktan tersebut dirintis atas dasar keprihatinan masyarakat terhadap kondisi lingkungan di perkotaan yang tidak hijau dan sejuk seperti di pedesaan. Luas lahan di perkotaan yang dapat dimanfaatkan untuk pertanian sangat terbatas. Oleh karenanya, dikembangkan sistem bercocok tanam secara vertikal yang dapat berkontribusi dalam ketersediaan pangan, lingkungan hidup.

UKDW sebagai salah satu instansi pendidikan yang berlokasi tidak jauh dari Kampung Bausaran terdorong untuk ambil bagian dalam usaha masyarakat untuk melakukan penghijauan di perkotaan. Pada tahun 2020, Fakultas Bioteknologi bersama Fakultas Bisnis UKDW melakukan sejumlah pendampingan masyarakat melalui program KKN Tematik di Kampung Sayur Bausasran. Pendampingan yang diberikan berfokus pada pengembangan kampung wisata edukasi berbasis pertanian perkotaan menuju masyarakat mandiri pangan [1]. Penataan lahan pertanian yang menarik, pelatihan manajemen dan keuangan dilakukan untuk mendukung tujuan tersebut.

Pada tahun 2020, Kampung Sayur Bausasran mendapatkan mandat serta bantuan dari Kementerian Pertanian untuk menjalankan program P2L (Pekarangan Pangan Lestari). Melalui program ini, pemerintah mendorong kegiatan pertanian perkotaan dapat berkembang ke arah pemenuhan kebutuhan pasar terhadap bahan pangan dan gizi. Oleh karena, sistem pertanian yang terintegrasi dari penanaman, pemanenan, penjualan hingga pembibitan penting untuk dilakukan

Diseminasi pengetahuan kepada masyarakat merupakan suatu proses yang berkelanjutan untuk dapat mencapai tujuan yang diharapkan. Kegiatan pengabdian sebelumnya menjadi landasan untuk mengembangkan dan memberikan pendampingan kepada masyarakat. Program pengabdian masyarakat dalam bentuk KKN Tematik Kota bekerjasama dengan Fakultas Bisnis, Fakultas Teknologi Informasi dan Fakultas Arsitektur dan Desain berupaya meningkatkan meningkatkan pertanian perkotaan di Kampung Bausasran melalui penerapan teknologi berbasis inovasi dan kreativitas. Kegiatan ini diharapkan dapat memberikan dampak yang positif bagi pemenuhan kebutuhan sayur di skala rumah tangga dan peningkatan perekonomian masyarakat.

\section{MASALAH}

Pandemi Covid 19 berdampak pada terjadinya pembatasan aktivitas manusia. Hal ini dilakukan untuk menurunkan dan mencegah terjadinya penularan virus SARS Cov 2. Pembatasan aktivitas dan kegiatan secara langsung berdampak pada tingkat produktivitas dan keterlibatan masyarakat dalam kegiatan kemasyarakatan. Hal ini berdampak pada sejumlah bibit dan tanaman yang terdapat di Kampung Sayur Bausasran. Pada kondisi pandemi, keterlibatan masyarakat dalam merawat tanaman di lahan pertanian perkotaan maupun lorong sayur menurun sehingga mengakibatkan penurunan produktivitas pertanian perkotaan.

Kondisi ini mendorong civitas akademika UKDW untuk membantu dan membangkitkan kembali kegiatan pertanian perkotaan di Kampung Sayur Bausasran dalam masa pandemi ini. Suatu studi menunjukkan adanya gerakan berbagai sembako oleh warga Bausasran dalam rangka mengatasi masalah ketahanan pangan bagi kelompok masyarakat yang rentan secara ekonomi di masa pandemi ini [2]. Ketersediaan sayur dari kebun maupun lorong sayur dapat menjadi salah satu alternatif pemenuhan kebutuhan pangan dan gizi bagi masyarakat terdampak. Konsumsi sayur yang cukup dapat meningkatkan sistem imunitas dan kualitas kesehatan masyarakat. Ketahanan pangan di era pandemi ini dapat ditingkatkan melalui urban farming karena dapat memenuhi kebutuhan pangan dan gizi bagi setiap anggota keluarga [3]. Selain itu, materi pendampingan dan pelatihan berfokus pada pengembangan 
dan inovasi produk pertanian, diversifikasi tanaman, administrrasi dan manajemen kelompok tani. Inovasi teknologi yang diberikan dapat membantu masyarakat dalam pengelolaan lahan pertanian. Kegiatan pengabdian ini diharapkan dapat mewujudkan Kampung Sayur Bausasran dengan sistem pertanian terintegrasi, mandiri pangan dan produktif di masa pandemi Covid 19.

\section{METODE PELAKSANAAN}

\section{A. Lokasi, Waktu dan Durasi Kegiatan}

Pendampingan dilakukan terhadap 6 kelompok tani dan 1 lahan Gerakan Pekarangan Pangan di Kampung Sayur Bausasran, Danurejan, Yogyakarta dengan menempatkan 1 kelompok mahasiswa untuk tiap kelompok tani. Kegiatan ini dilakukan selama 2 bulan yaitu Januari-Februari 2021 yang diikuti oleh 74 mahasiswa peserta yang terbagi dalam 7 kelompok.

\section{B. Metode Pendampingan Masyarakat}

Pendekatan pengabdian yang digunakan adalah Service Learning. Tahapan yang dilakukan dalam kegiatan pengabdian ini meliputi tahap persiapan, pelaksanaan dan evaluasi. Tahap persiapan terdiri atas analisa situasi masyarakat, identifikasi masalah, penentuan tujuan kerja, perencanaan penyelesaian masalah dan pendekatan sosial. Tahap persiapan dilakukan oleh tim pengabdian masyarakat. Analisa situasi masyarakat dilakukan secara langsung melalui proses wawancara terhadap masyarakat dan perangkat desa. Perkembangan situasi pandemi Covid 19 dan kebijakan pemerintah dipantau melalui media sosial. Perencanaan penyelesaian masalah dilakukan oleh tim pengabdian masyarakat, mahasiswa dan masyarakat terkait.

Tahap pelaksanaan terdiri atas penyusunan rencana kerja secara matang dan rinci. Pelaksanaan dilaksanakan secara hibrid, dimana pendampingan masyarakat dilakukan secara tidak langsung (dalam jaringan) dan langsung (luar jaringan) dengan persentase berturut-turut sebesar $60 \%$ dan $40 \%$. Perencanaan konsep dan material dilakukan di luar lokasi pengabdian. Metode pendampingan masyakat meliputi pelatihan, penerapan dan simulasi IPTEK.

Tahap evaluasi terdiri atas pelaporan pelaksanaan kegiatan yang dituangkan dalam bentuk laporan, presentasi dan pembuatan video dokumentasi. Selain itu, juga dilakukan penilaian kepuasan masyarakat terhadap kegiatan pengabdian yang dilakukan.

\section{HASIL DAN PEMBAHASAN}

Pertanian terintegrasi merupakan suatu konsep pertanian yang berkelanjutan dari proses pembibitan hingga pemanenan. Pertanian terintegrasi juga berorientasi pada konsep sistem produksi tanpa limbah (zero waste production system) dimana seluruh limbah dari tanaman dan ternak dapat diaur ulang dan dimanfaatkan kembali ke dalam siklus produksi [4]. Hal ini yang menjadi tujuan dari program P2L yang dicanangkan oleh Kementerian
Pertanian Indonesia. Melalui program ini, pertanian perkotaan diharapkan dapat berkembang tidak hanya untuk pemenuhan kebutuhan rumah tangga, namun juga memberikan kontribusi perekonomian bagi petani perkotaan. Berdasarkan hal tersebut, program pengabdian ini dilakukan untuk mendorong perwujudan P2L di Kampung Sayur Bausasran.

Berdasarkan wawancara yang dilakukan ke perangkat desa dan pengurus poktan, diketahui beberapa permasalahan yang dihadapi oleh poktan sebelum maupun selama masa pandemi Covid 19. Permasalahan tersebut meliputi sumber daya manusia, lahan pertanian terbatas, keterbatasan dana, rendahnya promosi serta administrasi kelompok tani yang belum termanajemen dengan baik. Oleh karena itu, terdapat 4 fokus program utama yang dilakukan yaitu SDM, usaha, lembaga dan lingkungan. Terdapat tiga tahap penting dalam pemberdayaan masyarakat Kampung Sayur Bausasran yaitu penyadaran, pengkapasitasan dan pemberian daya [5] .

Program mengenai pembinaan SDM dilaksanakan melalui serangkaian proses sosialisasi dan pelatihan di bidang pertanian. Secara umum, kegiatan meliputi pembuatan pupuk organik, biopestisida, mol, teknik hidroponik dan aquaponik. Kampung Sayur Bausasran merupakan daerah padat penduduk yang memiliki banyak lorong dan gang sempit sehingga teknik hidroponik sayuran secara sederhana tepat untuk diterapkan. Teknik hidroponik merupakan suatu metode menumbuhkan tanaman dengan menggunakan nutrisi berupa mineral yang terlarut dalam air sehingga tidak membutuhkan lahan yang luas. Selain itu, media tanam pada teknik ini dapat memanfaatkan botolbotol bekas sehingga mengatasi permasalahan botol plastik [6].

Kegiatan tersebut juga memanfaatkan sumber daya lokal di Kampung Sayur Bausasran seperti limbah organik dari rumah tangga maupun lahan pertanian dengan peralatan sederhana yang tersedia. Produk yang dihasilkan seperti pupuk organik maupun biopestisida dapat digunakan untuk meningkatkan produktivitas pertanian. Program tersebut menjadi solusi keterbatasan dana, fasilitas dan lokasi pertanian yang tersedia. Hal ini dapat memotivasi masyarakat untuk bercocok tanam dalam keterbatasan kondisi.

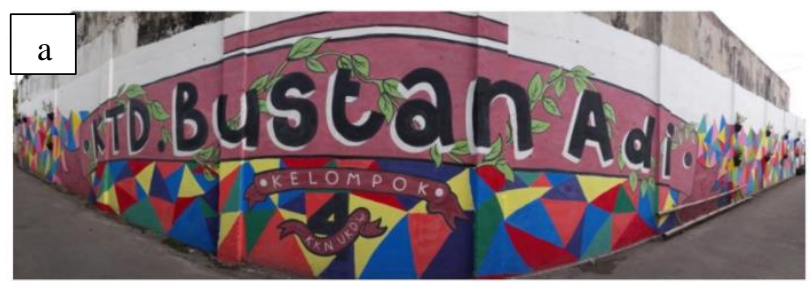



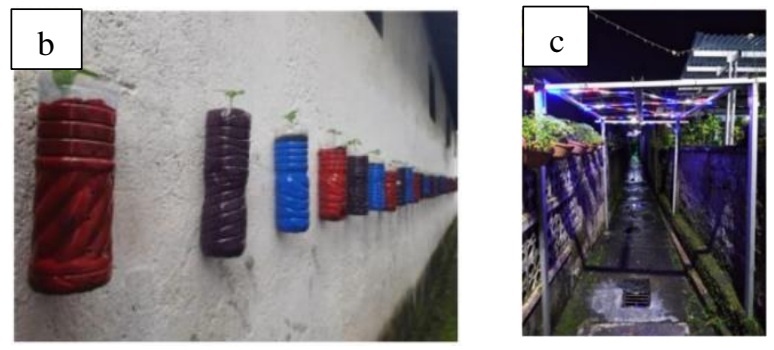

Gambar 1 (a) Mural lorong sayur, (b) Tanaman dalam pot di lorong sayur, (c) Penerangan lorong sayur.

Kegiatan tersebut juga memanfaatkan sumber daya lokal di Kampung Sayur Bausasran seperti limbah organik dari rumah tangga maupun lahan pertanian dengan peralatan sederhana yang tersedia. Produk yang dihasilkan seperti pupuk organik maupun biopestisida dapat digunakan untuk meningkatkan produktivitas pertanian. Program tersebut menjadi solusi keterbatasan dana, fasilitas dan lokasi pertanian yang tersedia. Hal ini dapat memotivasi masyarakat untuk bercocok tanam dalam keterbatasan kondisi.

Program pembinaan usaha diawali dengan pemetaan jenis usaha, keterbatasan, potensi, kekuatan dan keunikan masing-masing kelompok tani. Fokus pembinaan satu kelompok tani dengan kelompok lain tentu berbeda. Contohnya adalah kelompok tani Bustan Adi di RT 41-45 memiliki lorong dan lokasi pertanian terbatas. Oleh karena itu, program yang dilaksanakan berfokus pada lorong sayur, pembuatan mural dan penerangan jalan di lorong (Gambar 1). Mural dan penerangan ini bertujuan untuk memperindah lorong sayur sehingga masyarakat termotivasi untuk ikut terlibat menjaga sayur di sepanjang lorong.

Selain itu, lahan pertanian yang terbatas menuntut kegiatan bercocok tanam menggunakan pot sehingga perlu dilakukan pemilihan tanaman yang sesuai dan tepat. Berdasarkan hasil studi, dilakukan pelatihan budidaya tanaman jeruk santang madu dalam pot (Tabulampot). Tabulampot dapat diintegrasikan dengan tanaman pekarangan atau sayur lainnya sehingga meningkatkan variasi sumber gizi. Tanaman ini akan dikembangkan menjadi produk unggulan kelompok tani Bustan Adi. Jeruk santang madu merupakan salah satu jenis tanaman jeruk yang mampu dibudidayakan dalam pot. Secara umum, pertumbuhan tabulampot jeruk secara normal dengan umur 1,5-2 tahun telah mampu untuk berbuah [7].

Berbeda halnya dengan KTD Bustan Adi, kegiatan di KTD Gemah Ripah lebih berfokus dalam pembinaan promosi, administrasi dan manajemen. KTD Gemah Ripah merupakan salah satu KTD yang telah maju dalam bidang pertanian di Kota Yogyakarta. Oleh karena itu, diperlukan branding dan diversifikasi produk untuk meningkatkan daya tarik masyarakat. Adapun program yang dilaksanakan meliputi pembuatan website, akun media sosial untuk bisnis, pelatihan editing dan instalasi logo poktan.
Diversifikasi produk juga dilakukan di KTD Bonjowi. Hal ini dilakukan melalui pelatihan handsanitizer berbahan alam, simplisia dan ecoprint. Luaran dari kegiatan ini ditunjukkan pada Gambar 2.

Tahap pengembangan pertanian di KTD Gemah Ripah juga berjalan. Hal ini ditunjukkan dengan adanya inovasi budidaya lele dalam ember (Budikdamber) yang terintegrasi dengan tanaman kangkung. Budikdamber merupakan salah satu ebntuk pertanian terintegrasi antara ternak dan tanaman. Metode ini tepat digunakan di Kampung Sayur Bausasran yang memiliki keterbatasan lahan pertanian. Budikdamber dan akuaponik dapat digunakan sebagai salah solusi ketahanan pangan di masa pandemi karena mampu membantu perekonomian masyarakat [8].
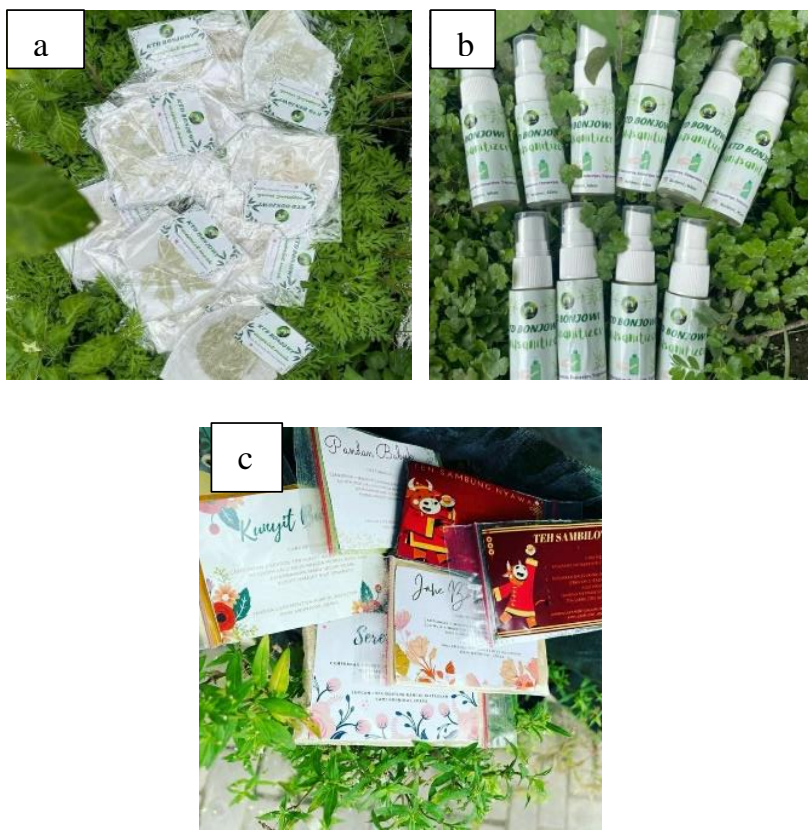

Gambar 2 (a) Masker ecoprinting, (b) handsanitizer herbal dan (c) simplisia.

Pengembangan produk olahan dari tanaman juga diberikan kepada KTD Manunggal Lestari. Rosella dan Telang merupakan tanaman yang dibudidayakan di KTD ini. Kedua tanaman ini mengandung antioksidan yang mampu menghambat radikal bebas dan mencegah timbulnya penyakit akibat degeneratif sel [9][10]. Melalui kegiatan ini, diberikan pelatihan pembuatan produk teh rosella dan bunga telang. Selain itu, juga dilakukan pendampingan pembuatan logo produk olahan tersebut untuk membantu promosi dan branding. 


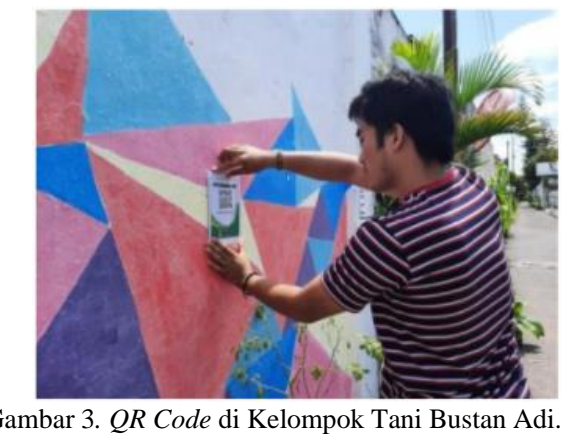

Selain sumber daya manusia dan usaha, lembaga juga merupakan salah satu terpenting dalam keberlangsungan suatu kelompok. Oleh karena itu, pembinaan kelompok tani juga dilakukan melalui pengenalan administrasi dan manajemen. Salah satu program yang dilakukan adalah penyediaan buku tamu yang dikemas dalam QR (Quick Response) Code. Hal ini dapat mempermudah pengurus untuk dokumentasi data pengunjung. Selain itu, penggunaan $Q R$ code yang mudah dan sederhana menjadi alternatif untuk mengurangi interaksi langsung antara pengurus dengan pengunjung di era new normal.

Saat ini, pengembangan Kampung Sayur Bausasran tidak bisa terlepas dari langkah promosi melalui media digital. Oleh sebab itu, pembuatan dan pelatihan penggunaan media publikasi digital diberikan kepada kelompok tani. Media digital berupa website dan media sosial instragram. Ketersediaan kedua jenis media digital tersebut memperkuat kegiatan promosi kebun sayur sebagai destinasi ekowisata maupun promosi sayur dan produkproduk pangan lainnya ke masyarakat luas.

Salah satu tujuan dari pendirian Kampung Sayur adalah fokus penghijauan di lingkungan perkotaan. Selain menciptakan kemandirian pangan dan perekonomian masyarakat, kegiatan pertanian kota juga akan mengajak warga untuk mengenal lebih dekat lingkungannya. Lingkungan yang dimaksudkan adalah lingkungan fisik dan lingkungan sosial. Peningkatan lingkungan fisik dapat diamati dari kondisi lingkungan yang hijau dan tidak gersang karena adanya tanaman di halaman rumah maupun lorong kampung. Lingkungan sosial adalah interaksi sosial antar warga yang meningkatkan melalui keterlibatan masyarakat dalam kegiatan bercocok tanam demi mencapai satu tujuan yaitu lingkungan hidup yang baik dan hijau.

Sejumlah diversifikasi produk olahan telah dilakukan dalam rangka mendukung pengembangan kelompok tani. Hal ini bertujuan untuk mendorong kemandirian kelompok tani dari sisi ekonomi dan pengembangannya ke arah usaha rumah tangga. Namun, pengujian mutu terhadap produk tersebut belum dilakukan sehingga keamanan pangan tersebut belum terjamin. Oleh karena itu, belum dilakukan penjualan berskala besar atau komersialisasi. Perijinan PIRT (Izin Pangan Industri Rumah Tangga) perlu dilakukan untuk menjamin keamanan pangan ini bagi konsumen.
Melalui izin P-IRT ini, produk olahan tersebut layak beredar dan dapat dipasarkan secara luas. Hal ini dikarenakan kepercayaan pembeli terhadap keamanan dan mutu produk meningkat.

Kegiatan pengabdian masyarakat ini merupakan suatu bentuk pelayanan institusi pendidikan, UKDW dalam rangka mendukung program pemerintah daerah setempat untuk melakukan penghijauan lingkungan dan peningkatan perekonomian masyarakat setempat melalui kegiatan pertanian perkotaan. Sejumlah diseminasi pengetahuan dan teknologi diharapkan menjadi modal bagi masyarakat untuk mempertahankan, mengembangkan dan memajukan pertanian perkotaan yang telah dirintis hingga nantinya dapat menjadi daerah agrowisata Kampung Sayur Bausasran sebagai tujuan utama. Namun keberlangsungan dan keberhasilan program ini tidak bisa terlepas dari peran dan dukungan masyarakat setempat. Masyarakat merupakan penggerak utama seluruh rangkaian proses mencapai daerah agrowisata. Oleh karena itu, pendampingan terhadap SDM sangat penting dilakukan untuk menyamakan visi dan misi demi tercapai tujuan akhir. Keberlangsungan program ini juga sangat memerlukan sumbangsih baik ide maupun energi dari masyarakat sehingga penyadaran SDM ini perlu ditingkatkan. Dukungan pemerintah dan institusi pendidikan juga dibutuhkan untuk membangun suatu program yang terrarah dan inovatif. Sebagai pihak luar, UKDW memberikan pendampingan, keterampilan dan pengetahuan yang dapat dilanjutkan oleh masyarakat secara mandiri. Kemandirian masyarakat dinilai sangat penting untuk menentukan keberhasilan program pengabdian ini. Pendampingan juga perlu dilakukan secara berkelanjutan untuk menggerakkan dan melatih kemandirian masyarakat. Melalui kegiatan pengabdian ini, civitas akademika UKDW juga memperoleh sejumlah pengalaman dan informasi terkait permasalahan yang dihadapi oleh masyarakat. Hal-hal tersebut merupakan sumber yang penting untuk mengembangkan dan mengasah pengetahuan, inovasi dan kreativitas yang dapat menjawab permasalahan secara nyata. Sejumlah solusi dirangkai dan disusun bersama dengan masyarakat setempat sehingga mampu menghasilkan solusi yang tepat sesuai kebutuhan masyarakat. Kolaborasi antara masyarakat, pemerintah setempat dan institusi pendidikan perlu didorong dan ditingkatkan untuk membangun suatu lingkungan dan kondisi ideal untuk mewujudkan visi dan misi sehingga mencapai tujuan utama yang diharapkan.

\section{KESIMPULAN}

Sejumlah program pendampingan yang dilakukan terhadap enam kelompok tani di Kampung Sayur Bausasran berkontribusi dalam proses penyadaran dan pengkapasitasan potensi lokal. Gang sempit dan lorong menjadi peluang untuk mengembangkan pertanian secara 
vertikal yang dapat mempercantik dan menghijaukan lingkungan. Pembinaan lembaga kelompok tani juga dilakukan dalam administrasi dan manajemen. Meskipun demikian, pembinaan terhadap masyarakat perlu ditingkatkan untuk meningkatkan motivasi dan keterlibatan masyarakat terhadap pertanian perkotaan. Pemetaan permasalahan dan potensi lokal juga perlu dilakukan untuk menyusun suatu program yang tepat untuk diterapkan dalam pengembangan Kampung Sayur Bausasran. Konsep pengembangan yang tepat dan terpadu dapat mengarahkan Kampung Sayur Bausasran ke arah kawasan ekowisata berbasis edukasi pertanian.

\section{UCAPAN TERIMA KASIH}

Dalam pelaksanaan program pengabdian masyarakat ini, tim pelaksana telah mendapat dukungan dari berbagai pihak. Oleh karena itu, kami mengucapkan terima kasih yang sebesar-besarnya kepada Lembaga Penelitian dan Pengabdian Masyarakat (LPPM) Universitas Kristen Duta Wacana Yogyakarta, Kelompok Tani Gemah Ripah, dan warga Kalurahan Bausasran Yogyakarta yang telah mendukung program pengabdian dalam bentuk KKN Tematik Kota. Ucapan terima kasih juga ditujukan kepada Wida Hening Sukma Crisdiati, S. Pd. dan Arga Nugraha, S.Si. yang merupakan bagian tim pelaksana KKN Tematik Kota.

\section{DAFTAR PUSTAKA}

[1] D. Rahardjo, C. A. Ariestanti, A. Prasetyaningsih, D. Aditiyarini, K. Madyaningrana, and J. Herdioko, "Pemberdayaan Kelompok Tani Gemah Ripah Kelurahan Bausasran Menuju Kampung Mandiri Pangan dan Ekowisata Perkotaan," Pros. Sendimas 2020, vol. 5, no. 1, pp. 336-338, 2020.

[2] R. Istriyani and M. F. Rahman, "Representasi Masyarakat Aktif di
Masa Pandemi Covid-19 (Studi Ekonomi dan Sosial Keberagamaan di Bausasran Danurejan Yogyakarta)," J. Penelit., vol. 14, no. 2, p. 185, 2020.

[3] N. Kharima, Yulianti, and Y. Indrasari, "Keberfungsian Urban Farming Terhadap Ketahanan Pangan Keluarga di Masa Pandemi Covid 19," JKPS J. Kesejaht. dan Pelayanan Sos., vol. 2, no. 1, pp. 25-43, 2021.

[4] I. S. Anugrah, S. Sarwoprasodjo, K. Suradisastra, and N. Purnaningsih, "Sistem Pertanian Terintegrasi-SIMANTRI: Konsep, Pelaksanaan dan Perannya dalam Pembangun Pertanian di Provinsi Bali," Forum Penelit. Agro Ekon., vol. 32, no. 2, pp. 157-176, 2014.

[5] K. T. Aristina, E. Murdiyanto, and T. Kismantoroadji, "Pemberdayaan Masyarakat Kampung Bausasran oleh Pemerintah Kota melalui Program Kampung Sayur," Pros. 2nd Semin. Nas. ADPI Mengabdi untuk Negeri Pengabdi. Masy. di Era New Norm., vol. 2, no. 2, pp. 216-220, 2021.

[6] F. Damayanti, and T. Supriyatin, "Bercocok Tanam Dengan Sistem Hidroponik Berbasis Ramah Lingkungan Melalui Pemanfaatan Sampah Botol Plastik Planting with Environment-Based Hydroponic Systems Using Plastic Bottle," J. Pelayanan dan Pengabdi. Masy. vol. 4, no. 1, pp. 2685-5968, 2020.

[7] M. F. U. Ariza, Teknologi Budidaya Tabulampot Jeruk. Balai Pengkajian Teknologi Pertanian Papua Barat, Badan Penelitian dan Pengembangan Pertanian, 2020.

[8] D. Setiyaningsih, H. Bahar, R. Aulia, A. Al-mas, and K. T. Selatan, "Penerapan Sistem Budidaya Budikdamber dan Akuaponik sebagai Strategi dalam Memperkuat Ketahanan Pangan di Tengah Pandemi COVID-19," Semin. Nas. Pengabdi. Masy. LPPM UMJ, pp. 1-10, 2020.

[9] D. Andriani and L. Murtisiwi, "Uji Aktivitas Antioksidan Ekstrak Etanol 70\% Bunga Telang (Clitoria ternatea L) dari Daerah Sleman dengan Metode DPPH," Pharmacon J. Farm. Indones., vol. 17, no. 1, pp. 70-76, 2020.

[10] M. Inggrid, Y. Hartanto, and J. F. Widjaja, "Karakteristik Antioksidan pada Kelopak Bunga Rosella (Hibiscus sabdariffa Linn.)," $J$. Rekayasa Hijau, vol. 2, no. 3, pp. 283-289, 2018. 